\section{La obra de arte como crítica de arquitectura}

Alejandro Crispiani Profesor, Pontificia Universidad Católica de Chile

La crítica de arquitectura ha llegado a ser una disciplina en si misma. Las instalaciones de Dan Graham buscan analizar a la arquitectura desde la puesta en escena de lugares donde se extreman diversas situaciones. Se constituyen como obras en tres dimensiones que no buscan publicidad, sino borrar las barreras entre arte y crítica.

En 1975 el artista norteamericano Dan Graham realizó una obra en la John Gibson Gallery de Nueva York titulada Yesterday/today. En términos generales podría describírsela como una instalación, un género en rigor poco desarrollado por Graham cuya producción se caracteriza por la búsqueda de objetos polivalentes, que sin negar los géneros artísticos, parecen calzar naturalmente en varios de ellos a la vez. La obra, particularmente sedante y concentrada, consistía en lo siguiente: en el espacio de la galería, sobre un pedestal blanco y prismático, se hallaba un aparato de televisión; a un costado de él, en el suelo, había un parlante. El aparato mostraba imágenes tomadas en ese mismo momento, por medio de una cámara de video, de lo que ocurría en una habitación contigua a la sala de exposiciones, que se utilizaba para la administración de la galería y también como salón de reuniones. Por momentos, podía verse en la pantalla a un grupo de asistentes a la galería discutiendo sobre la obra de Graham o sobre arte en general, ya que la habitación donde estaba instalada la cámara era accesible al público. También podía mostrar la actividad diaria de administración de la galería. Desde el parlante podían escucharse las conversaciones y los sonidos que se habían producido en esa misma habitación, pero el día anterior. Las imágenes de la pantalla mostraban lo que estaba ocurriendo en ese momento en la sala de reuniones, pero el registro sonoro que acompañaba a esas imágenes databa de 24 horas antes. Las imágenes eran actuales, pero el sonido atrasaba 24 horas. Alguien que hubiera visitado la obra y participado de las conversaciones, que evidentemente eran una parte central de la misma, ya que representaban su dato visual más llamativo y eran constitutivas por lo tanto de su forma, podría volver al día siguiente y oír lo dicho el día anterior. En ese momento la obra quedaba completa. El público estaba invitado a participar con su propia imagen y su propia voz en la forma visual y sonora de la obra, pudiendo de todas maneras mantenerse en la clásica posición del espectador que sólo observa, si decidiera no pasar a la habitación adyacente a la galería donde se tomaban las imágenes. (Fig 01)

En la obra de Graham, la pantalla de televisión ha reemplazado al cuadro, con el que mantiene igualmente ciertos vínculos. En primer lugar, se encuentra en una galería de arte y es también una suerte de ventana hacia un universo de imágenes. Pero a diferencia de lo que ocurre en general con los cuadros, el espectador tiene la posibilidad de aparecer en la pantalla y ser parte del mundo de imágenes que construye la obra. En la pintura esto sucede excepcionalmente. Podría ocurrir que alguien se contemplara a sí mismo en un cuadro colgado en una galería de arte. Esto no puede pasar en la obra de Graham: el espectador consigue aparecer en pantalla y ser parte del conjunto de imágenes que constituyen la obra, pero por tratarse de imágenes en tiempo real y al estar localizada la cámara que las genera en otra habitación, él nunca puede ver su propia imagen. No logra verse a sí mismo en la pantalla. En tal sentido, si bien se lo invita a parti-

\section{A work of art as an architectural critique}

Alejandro Crispiani Professor, Pontificia Universidad Católica de Chile

Architectural criticism has become a discipline in itself. The installations of Dan Graham seek to analyze architecture from the spotlight of arriving at extremes in diverse situations. They are built like three dimensional works that seek not publicity but to erase the barriers between art and criticism.

In 1975, the North American artist, Dan Graham created a work in the John Gibson Gallery of New York titled Yesterday/today. In general terms, one could describe it as an installation, a genre little used by Graham, whose work is characterized by the search for versatile objects. Without rejecting artistic genres, the piece appears to naturally fit within various categories simultaneously. The piece, particularly palliative and concentrated, consists of the following: in a gallery space sits a television set on a white prism of pedestal; on the floor to its side is a speaker. The apparatus shows simultaneous images taken by a video camera in a room next to the exposition room used as a conference room for the gallery administration. Because the adjacent room is accessible to the public, in moments you can see groups of gallery visitors discussing the Graham piece and art in general as well as the daily administration of the gallery. From the speaker one hears the conversations and sounds produced in that same room, but from 24 hours previous. That is to say, the screen shows the present activity and the speaker the registry of the day before. Someone that had visited the work and participated in the conversations, a central part of the piece and its most striking component, and who were constituents in its form can return the next day and hear what they said the day before. In this moment the work is complete. The public is invited to participate with their own image and voice, yet are allowed to maintain themselves in the classic position of being a simple observer if they decide to not enter the adjacent room being filmed. (Figs 01 y 02)

In Graham's piece, the television screen has replaced the painting. Yet certain ties remain. In the first place, it is located in an art gallery which is in a way a window to the universe of images. Yet contradictory to the norm of a painting, the spectator has the possibility of appearing on the screen and be part of the image-world built by the work. In painting, this happens from time to time. It could occur when one contemplates himself in a painting hung in a gallery, but this is impossible in Graham's piece. The spectator can appear on the screen and be part of the collection of images the work creates, but because the images appear in real time and the camera filming is located in the other room, he can never see his own image. He can never see himself on the screen. In this way, even while one is invited to participate in the image universe of the piece, a distinction is maintained between viewer and participant. A similar tactic is applied to the accompanying sounds. Here the participant is also subject to a certain split. The conversation, the sounds produced while in the meeting room, do not accompany the image on the television but are recorded and played the next day. One cannot speak and hear themselves through the speaker accompanying the screen in the art gallery. The spectator's voice will appear with the images of other participants. What I see now, what I hear is yesterday. As characteristic of Graham's production, Yesterday/today is presented without raucousness nor appealing to a spectacle of intimidation, instead it builds an aesthetic distance starting with the displacement of four pairs of notions quite recognizable: the seen and 
' Para un estudio más completo

sobre esta obra ver Graham, 1977.

2 Puede verse particularmente el

capítulo "El quid del minimalismo"

(Foster, 2001)

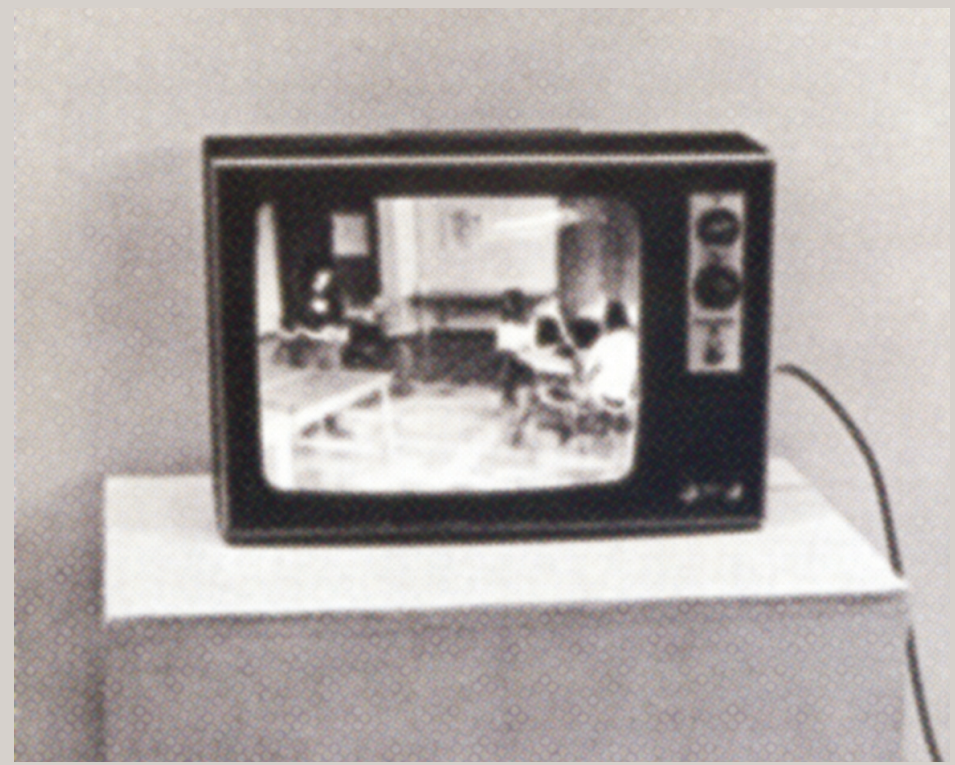

01 Dan Graham. Yesterday/today. John Gibson Gallery, Nueva York, 1975

Fuente: AA.W. Dan Graham. Architecture. Camden Arts Center, Londres, 1997, pp. 21 y 22

01 Dan Graham. Yesterday/today. John Gibson Gallery, New York, 1975

Source: AA.W. Dan Graham. Architecture. Camden Arts Center, London, 1997, pp. 21 y 22

cipar en el universo de imágenes involucradas en la obra, se mantiene la distinción entre espectador y participante. Una táctica similar se aplica a los sonidos que acompañan a las imágenes visuales. También aquí el participante está sujeto a una cierta escisión. Su conversación, los sonidos que produce cuando está en la sala de reuniones, no acompañan a su imagen en la pantalla de la galería, sino que son grabadas y reproducidas un día después. No puede hablar y escucharse por el parlante que acompaña a la pantalla en la sala de la galería. Su voz aparecerá acompañando las imágenes de otras personas. Lo que veo es ahora, lo que oigo es de ayer. Como es característico de la producción de Graham, Yesterday/today se presenta sin estridencias y sin apelar a ningún tipo de espectacularidad en última instancia intimidante, construye su distancia estética a partir del desplazamiento de cuatro pares de nociones bien reconocibles: lo visto y lo oído, lo real y lo representado (o la reproducción de lo real), el presente y el pasado, y el espacio y el tiempo. ${ }^{1}$

Desde esa base, las lecturas de Yesterday/today pueden seguir múltiples caminos, algunos de ellos ensayados por el propio Dan Graham. Pero más allá de estas lecturas, lo que es innegable es que la obra recoge con particular sobriedad y laconismo, pero no sin cierta intensidad, la renovación casi completa que sufrió el concepto de obra de arte durante los años sesenta, tema debatido en múltiples frentes teóricos y del cual el arte conceptual fue una de sus expresiones más netas, aunque no la más radical. Solitario en medio de la galería, aunque no sin nobleza y mucho menos abandonado ya que se encuentra sobre un pedestal, el aparato de televisión de Yesterday/today -que es el núcleo material de la obra- apunta a los inicios del arte conceptual y a la obra de Marcel Duchamp; también en este caso, particularmente activada a partir de su posible consideración como una forma de video-arte. La concentración del sentido y de los recursos formales, la intención de que el espectador se vea interpelado como un individuo concreto y que puede demostrar frente a la obra de arte su propia individualidad y en última instancia su resistencia frente al status-quo (finalmente, esa actividad básica de la vida contemporánea que es mirar televisión se halla trastocada críticamente, aunque no de una manera agresiva, sino más bien de un modo insidioso) conectan a esta
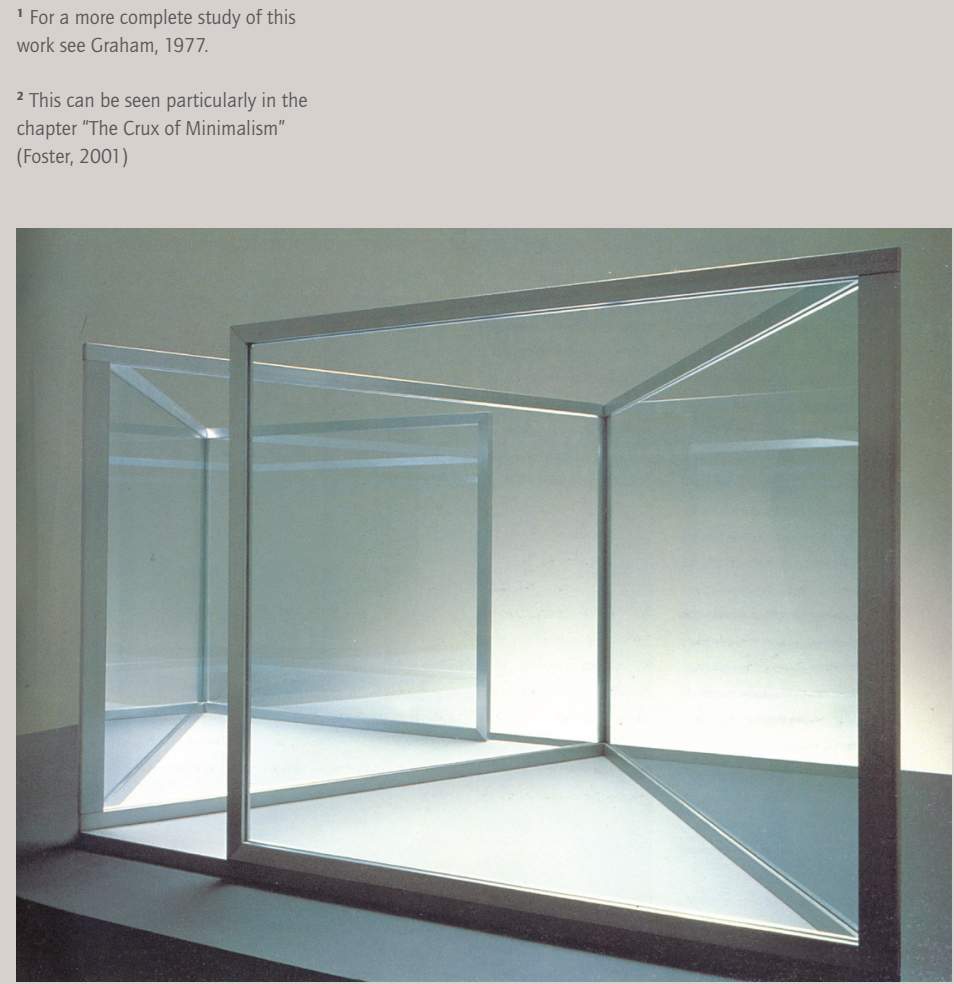

02 Dan Graham. Coffee shop, 1989-1991

Fuente: AA.W. Dan Graham. Architecture. Camden Arts Center, Londres, 1997, p. 33

O2 Dan Graham. Coffee shop, 1989-1991

Source: AA.W. Dan Graham. Architecture. Camden Arts Center, London, 1997, p. 33

the heard, the real and the represented (or the reproduction of the real). the present and the past, space and time. ${ }^{1}$

From this base, the interpretations of Yesterday/today can follow multiple paths, some of which are presented by Dan Graham himself. More important than these interpretations is the undeniable way this piece emits a particular sobriety and conciseness though not lacking in intensity. The almost complete redefinition the concept of "artwork" suffered during the seventies, a theme debated on multiple theoretical fronts from which conceptual art was one of its clearest, though not the most radical, expressions. Alone in the middle of the gallery, yet not without nobility, found on a pedestal, the television set of Yesterday/today -the nucleus of the piece- recalls the beginnings of conceptual art and the work of Marcel Duchamp. also in this case, this reference is particularly activated from its possible consideration as a form of video-arte. The concentration of meaning and formal resources, and the intention that the viewer is seen interpolated as a concrete individual and can demonstrate to the artwork his own individuality and ultimately his resistance to the statusquo (that basic activity in contemporary life of watching television is shown jumbled critically, not aggressively but insidiously). The work is certainly closely linked with minimalism and from there, indirectly, with geometric abstraction. In a movement already described by Hal Foster (2001) ${ }^{2}$, Yesterday/ today demonstrates the buried yet intense relationships between conceptual art and geometric abstraction, informal relationships that affect its feeling and placement. Graham's following work, particularly his pavilions from the eighties and nineties (Fig. 03), verify his links to abstraction. In Yesterday/today Graham places these relationships between minimalism, conceptual art, and abstraction in the new conquered territories of video-art and installation among the other currents of the sixties and seventies. Actually, Dan Graham sees this piece as many things at the same time, evoking various genres: an installation, a display of video-art, a recital of music both concrete and fortuitous, a sculpture in the line of ready-mades, etc. All depends on the degree and method in which the spectator involves himself. Also, one can evaluate this piece as an exercise in the critique of architecture.

To begin, it's worth noting that in considering Yesterday/today as an operation to be inscribed among critics, Graham is remaining faithful to one of 
obra ciertamente con el minimalismo y desde él, indirectamente, con la abstracción geométrica. En un movimiento que ya ha sido descrito por Hal Foster (2001), Yesterday/today da cuenta de las subterráneas pero intensas relaciones entre arte conceptual y abstracción geométrica, relaciones que no son formales sino que afectan al sentido y a la ubicación que se le quiere dar al arte. La obra posterior de Graham, particularmente sus pabellones de los años ochenta y noventa (Fig. 02), verifican justamente sus vínculos con la abstracción. En Yesterday/today Graham instala estas relaciones entre minimalismo, arte conceptual y abstracción en los nuevos territorios conquistados para el arte por el video-arte y las instalaciones, entre otras corrientes de los años sesenta y setenta. En rigor, Dan Graham ve a esta obra suya como muchas cosas a la vez, conteniendo varios géneros: una instalación, una muestra de video-arte, una audición de música concreta y aleatoria, una escultura en la línea de los ready-mades, etc. Todo depende del grado y de los modos en que el espectador se involucre con la misma. Pero también considera a ésta y a otras de sus obras como un ejercicio de crítica de la arquitectura.

Sus obras pueden ser vistas como crítica de arte o de arquitectura hecha con otros medios, distintos a los del lenguaje escrito. Comparte una posición con respecto a la arquitectura comparable a la de otros escultores, como Gordon Matta Clark o más recientemente Rachel Whiteread, en el sentido de mostrar lo que no se ve, de abrir la cotidianeidad de la obra de arquitectura a un trabajo de exploración formal que la reconstituye de otra manera impensada pero a la vez familiar con la obra en sí, como ocurre en Alteración de una casa suburbana del propio Graham de 1978 (Fig. 03) o en House de Rachel Whiteread de 1993. (Fig. 04) ¿Pero qué tipo de crítica de arquitectura es la ensayada por Graham con sus obras? ¿Cuál es el alcance y la productividad, por ejemplo, de Yesterday/today? En principio se trata de una crítica que no dice nada con respecto a problemas formales, que no ofrece ni soluciones ni inspiración para este tipo de consideraciones. En tal sentido, Yesterday/today difiere de obras posteriores de Graham, como sus pabellones, que podrían prestarse a las mismas, aunque claramente no es su espíritu. Yesterday/today es, desde su misma forma, crítica no-operativa en estado puro. Pero tampoco se presta para la crítica ideológica. En rigor es crítica en el sentido que separa y aísla fenómenos que hacen a la percepción y al sentido del espacio habitable. Recombina distintas cosas. Prepara una habitación para mostrarnos otra. Nos muestra un espacio representado en el que nos propone entrar y que, si bien es completamente real y concreto, en cierta forma aparece convertido en ficción al haber sido conocido por primera vez a través de una pantalla de televisión. Lo visto y lo oído se desarticulan frente a la obra (la pantalla), para rearticularse al entrar en la habitación real. En ella puedo imaginarme a mí mismo saliendo en la pantalla de televisión y siendo observado por el público de arte, lo que acentúa el desdoblamiento. Lo que no le está permitido a quien participa de la obra es verse en la pantalla. Esta imagen reparadora, se le escatima: para oírse, deberá esperar 24 horas. En síntesis, rompe la coordinación habitual de las múltiples imágenes con que solemos armar el rompecabezas del espacio en que habitamos. Propone, por lo tanto, una manera un tanto irreal de habitar el espacio arquitectónico, signada por el accionar de la cámara y el aparato reproductor de las imágenes que ésta capta. Esta presencia es dominante. No incide en la forma del espacio o de la caja arquitectónica en que ambos artefactos se hallan contenidos, sino en el sentido que este espacio adquiere. Su captura y reproducción en otro lugar, la conciencia de la cámara en los habitantes de ese espacio, son condiciones y posibilidades con los que la obra de Graham juega, sin abusar tampoco demasiado de ellas, pero poniéndolas sobre la mesa.

La obra de arte como crítica de arquitectura no solamente llama a la consideración de este fenómeno que en estos momentos ya parece universal the central features of this redefinition of "artwork" mentioned earlier. An important impulse proceeding this renewal was the blurring of borders between works of art and their criticism. Criticism was justly understood as an additional moment in the making of the work, a constituent part from which its aesthetic value was construed. Many critics, as in the demonstrative case of Lucy Lippard, to cite only a name, saw its production as eminently artistic; in fact, in many cases, as a work in itself. It does not deal simply with recognizing that all artwork entails a critical vision in one way or another, but thinking of the criticism as a form with aesthetic content that can be absorbed by a predisposed piece of art.. Or be the work itself. The usual form of critique, generally the written discussion made public, could be thought of as part of the piece, a component of its total form. The distinction between the artist and the critic is annulled. In a certain way, this was the case for Dan Graham, who began his career at the beginnings of the sixties as an art critic, an activity that later remained in the background of his image as an artist, but should not be discounted when appreciating his work. It serves to mark that this manner of thinking about art and its accompanying criticism at some point implies that a piece of art is responsible for the conditions of its reception. It does not imply -particularly in the case of Dan Graham- that it seeks some kind of mass popular impact (impact that the work of Graham despised) nor cultural, nor other kind of, provocation.

Options that in one case took conceptual art or associated actions of art. The work of Graham understands criticism as a game intimately reflective and anchored in the personal to make other stratum of the real appear, like a profound and discreet operation that rather tan be impressive wants to be close and persuasive.

His works can be seen as critique of art or architecture made with other medias different from the written language. They share a position with respect to architecture comparable to that of other sculptors, like Gordon Matta Clark o more recently Rachel Whiteread, in the sense of showing what is not seen, of opening the daily routine of the work of architecture to a work of formal exploration reconstituting in an surprising yet simultaneously familiar way with the work as occurred in Alteration of a suburban house by Graham in 1978 (Fig. 04) o in House by Rachel Whiteread in 1993. (Fig. 05) But what kind of architecture criticism is practiced by Graham in his works? What is the goal and output, for example, of Yesterday/today? To start, it deals with a critique that says nothing in respect to formal problems not offering solutions nor inspiration for this kind of considerations. In this sense, Yesterday/today differs from the later works of Graham, such as his pavilions, in that it could be understood to have the same aspirations yet clearly is not its intention. que podrían prestarse a las mismas, aunque claramente no es su espíritu. Yesterday/today is, in its own form, a non-operating critique in its pure state. But neither does it lend itself to ideological critique. Actually it is a critique in the sense that it separates and isolates phenomena that make the perception and feeling of the space inhabitable. It combines different things. It prepares the room to show us another. It shows us the space represented so at to probe us to enter being completely real and concrete as well. In a certain way it appears to convert the space into fiction for having seen it for the first time on the television screen. The seen and heard are dismantled in the work itself (the screen) and then reassembled upon entrance into the actual room. Here I can imagine myself appearing on the television screen and being observed by the art public accentuating the split. Those who participate are unable to see themselves on the screen. This rejoining image is denied: to hear oneself, one must wait 24 hours. In summary, it breaks down the coordination of habit we usually use to put together the puzzle of the space we inhabit. It proposes, however, a fantastical way to inhabit the architectonic space denoted by the action of the camera and the reproduction of the images it captures. This presence is dominant. It does not affect the form of the space nor the architectonic box in which both artifacts are placed but 


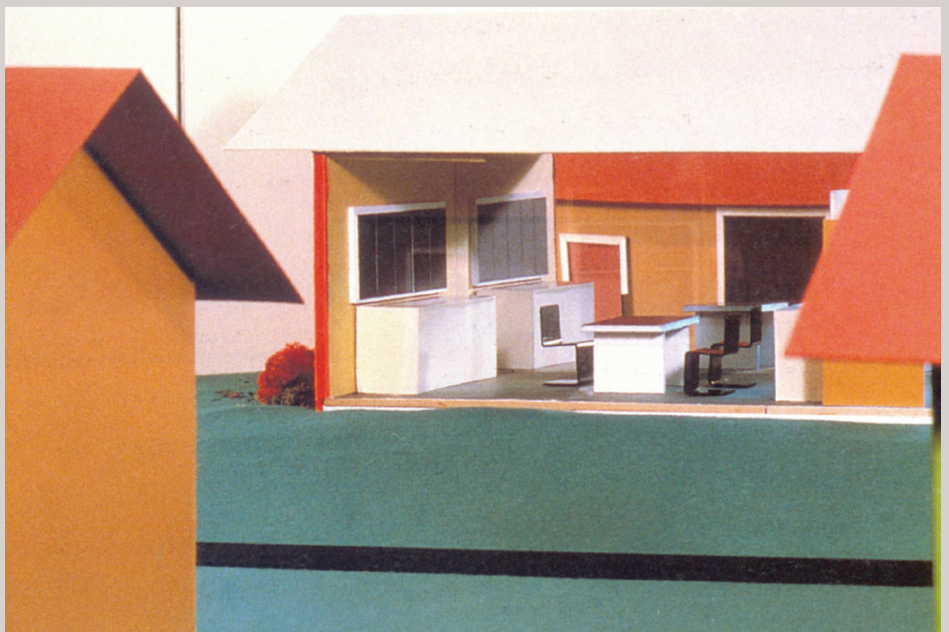

03 Dan Graham. Alteration of a suburban house, 1978

Fuente: AA.W. Dan Graham. Architecture. Camden Arts Center, Londres, 1997, p. 25 03 Dan Graham. Alteration of a suburban house, 1978

Source: AA.W. Dan Graham. Architecture. Camden Arts Center, London, 1997, p. 25

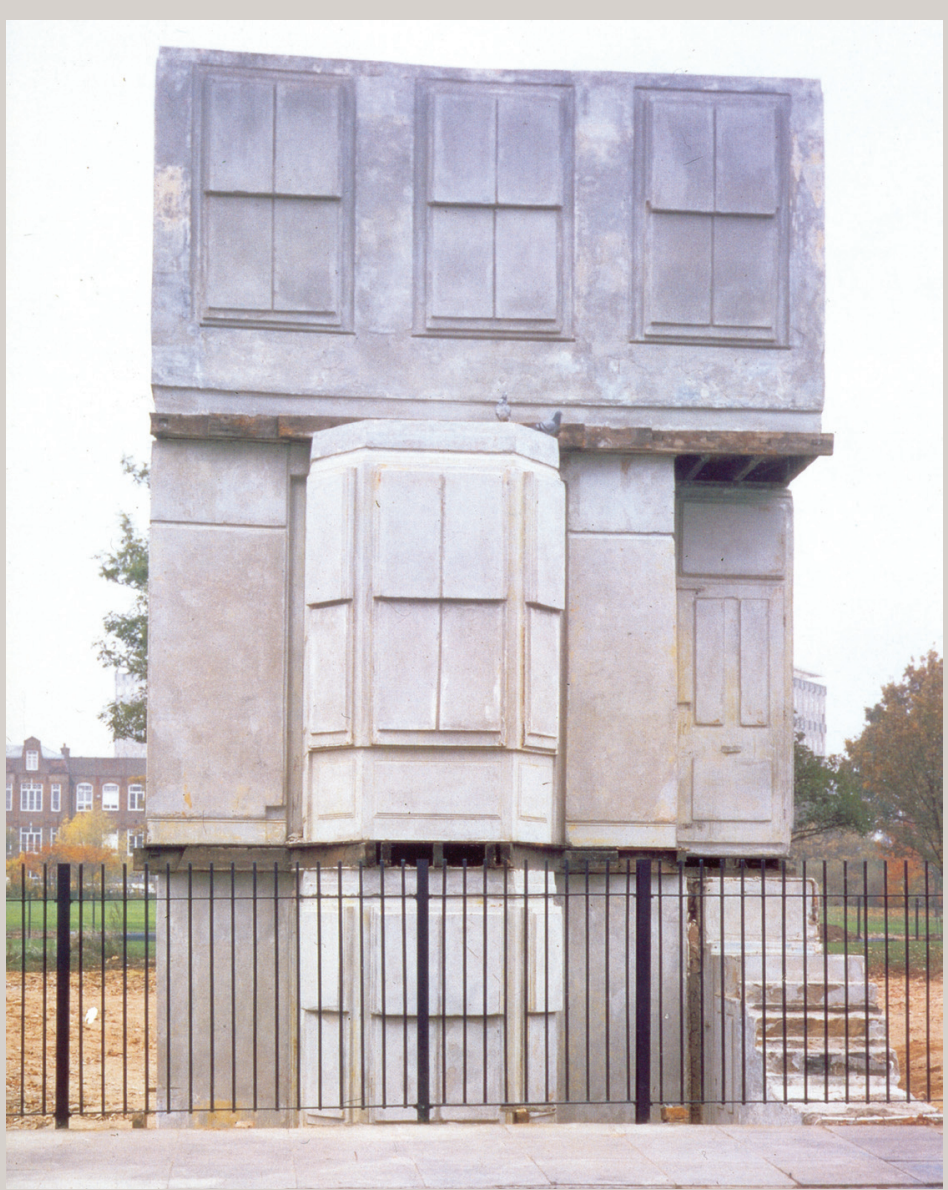

04 Rachel Whiteread. Untitled (House), Grove Road, Londres, 1993

Fuente: Mullins, Charlotte. Rachel Whiteread. Tate Publishing, Londres, 2004, p. 55 04 Rachel Whiteread. Untitled (House), Grove Road, Londres, 1993

Fuente: Mullins, Charlotte. Rachel Whiteread. Tate Publishing, Londres, 2004, p. 55 y del que casi no se escapa ningún espacio público, hoy por hoy poblados de cámaras de captura de imágenes y de pantallas en todo tipo de formato y tamaño, sino que nos somete a una experiencia inédita en relación con ellos. Una experiencia que, pensemos lo que pensemos de ella, quiere ser estética y quiere también mostrar la posibilidad de que este fenómeno sea manipulable en otros términos que los actuales. La cámara y el monitor producen una mediación con el espacio que habitamos de una intensidad desconocida hasta el momento actual. Casi no hay espacio público que no esté siendo monitoreado de manera sistemática, por mencionar sólo uno de los regímenes de sentido a los que la dupla cámara-monitor puede someter al espacio arquitectónico. A las características del espacio moderno ya conocidas, como ser la de una aclimatación perfecta, habría que sumarle esta otra, la de estar en constante reproducción y duplicación. Como bien ha señalado Beatriz Colomina (2006), quien también se ha ocupado de la obra de Dan Graham, este espacio suele ser doblemente público a la vez que tiende a penetrar cada vez más en lo privado, que paradójicamente quiere hacerse, también, cada vez más privado. La obra de Graham despierta estos temas e insinúa una forma estética de pensarlos; es un movimiento de exploración de una cierta condición del espacio moderno, movimiento del que nosotros no podemos ya participar fisicamente, pero que podemos reconstruir con nuestra imaginación. Esto es parte de las intenciones de la obra y de su proceder con respecto a sus posibilidades de recepción. Es una experiencia que genera una forma artística en múltiples registros, entre los que no está ausente la arquitectura, aunque sólo tome de ella -para jugar con él de variadas maneras-el hecho básico de que cuando estoy en una habitación no estoy en otra. ARQ

\section{Bibliografía}

AA.VV. Dan Graham. Architecture. Camden Arts Center, Londres, 1997. / Colomina, Beatriz. "Doble exposición: Alteración de una casa suburbana". En Doble exposición. Akal, Madrid, 2006. / Foster, Hal. "El quid del minimalismo". En El retorno de lo real. La vanguardia a finales de siglo. Akal, Madrid, 2001. the feeling that this space acquires. Its capture and reproduction in another location, the awareness of the camera to the inhabitants of the space are conditions and possibilities with which Graham's work plays ,without overuse, by placing them on the table.

The work of art as an architectural critique not only calls to consideration the now pervasive, daily phenomenon that almost no public space escapes, inundated with cameras, image capture, and screens of all kinds of formats and sizes but that gives us an new experience in relation to them. An experience, that we think what we think of it, wants to be aesthetic as well as show the possibility that this phenomenon be manipulable in other terms than just the current ones. The camera and the monitor produce a mediation with the space we inhabit of an intensity unknown until now. There is almost no public space that is not being monitored in some systematic way, to mention one of the systems of perception the camera-monitor duo can submit to architectonic space. To the already known characteristics of modern space, such as situating itself perfectly in its site, one must add being in constant reproduction and duplication. As Beatriz Colomina has pointed out (2006), who has also studied Graham's work, this space is usually public while simultaneously set to penetrate privacy more every time, that paradoxically wants to make itself more private. Graham's work awakens these themes and insinuates an aesthetic for contemplation; it is a movement of exploration from a certain condition of modern space, movement that we can physically participate in but cannot rebuild with our imagination. This is part of the intention of the piece, and from its conduct with respect to the possibilities of reception. It is an experience that generates an artistic form on multiple registers, among which is not absent the architecture, how ever using only -to play with it in various waysthe basic fact that when I am in a room I am not in another room. ARQ

\section{Bibliography}

AA.VV. Dan Graham. Architecture. Camden Arts Center, London, 1997. / Colomina, Beatriz. "Doble exposición: Alteración de una casa suburbana”. In Doble exposición. Akal, Madrid, 2006. / Foster, Hal. "El quid del minimalismo”. In El retorno de lo real.La vanguardia a finales de siglo. Akal, Madrid, 2001. 